\title{
INVESTIGATIONS OF HISTORICAL CITIES OF UZBEKISTAN AND KAZAKHSTAN AS OBJECTS OF THE SILK WAY
}

\author{
A.Zh. Zhussupbekov ${ }^{1}$, F.S. Temirova ${ }^{2}$,A.A. Riskulov ${ }^{3}$, A.R. Omarov ${ }^{1}$ \\ ${ }^{1}$ L.N. Gumilyov Eurasian National University, Nur-Sultan city, KAZAKHSTAN \\ ${ }^{2}$ Karshi Engeneering-Economics Institute, Karshi city, UZBEKISTAN \\ ${ }^{3}$ Tashkent Institute of Design, Construction and of Automobile Roads, Tashkent, UZBEKISTAN
}

\begin{abstract}
Since ancient times, the cities of Uzbekistan and Kazakstan have gained worldwide fame, like pearls scattered along the Great Silk Road, they sparkle under the bright sun. Cities of modern Uzbekistan have existed for thousands of years - Tashkent (2200 years), Termez, Bukhara, Khiva (2500 years), Shakhrisabz and Karshi (2700 years), Samarkand (2750 years), Margilan (2000 years), Almaty (1000 years), Turkestan (2000 years), Chimkent (2200 years) and Taraz (2000 years). In Uzbekistan and Kazakhstan, numerous collections, repositories, archives and libraries preserve the richest collections of manuscripts collected over many centuries. And all thanks to its favorable location in a picturesque oasis, almost in the center of the network of roads of the Great Silk Road.
\end{abstract}

Keywords: Central Asia, historical monuments, Hodge Ahmed Yassavi, Arystan-Bab, Palace Ak-Sarai

\section{ИССЛЕДОВАНИЯ ИСТОРИЧЕСКИХ ГОРОДОВ УЗБЕКИСТАНА И КАЗАХСТАНА КАК ОБЪЕКТОВ ШЕЛКОВОГО ПУТИ}

\author{
А.Ж. Жусупбеков ${ }^{1}$, Ф.С. Темирова ${ }^{2}$, А.А. Рискулов $^{3}$, А.Р. Омарова ${ }^{1}$ \\ ${ }^{1}$ Евразийский национальный университет им. Л.Н. Гумилева, город Нур-Султан, КАЗАХСТАН \\ ${ }^{2}$ Каршинский инженерно-экономический институт, г. Карши, УЗБЕКИСТАН \\ ${ }^{3}$ Ташкентский институт по проектированию, строительству и эксплуатации автомобильных дорог, \\ Ташкент, УЗБЕКИСТАН
}

\begin{abstract}
Аннотация: С древних времен города Узбекистана и Казахстана приобрели всемирную известность: жемчужины, разбросанные по Великому шелковому пути, сверкают под ярким солнцем. Города современного Узбекистана существуют тысячи лет - Ташкент (2200 лет), Термез, Бухара, Хива (2500 лет), Шахрисабз и Карши (2700 лет), Самарканд (2750 лет), Маргилан (2000 лет), Алматы (1000 лет), Туркестан (2000 лет), Чимкент (2200 лет) и Тараз (2000 лет). В Узбекистане и Казахстане многочисленные коллекции, хранилища, архивы и библиотеки хранят самые богатые собрания рукописей, формировавшиеся многие столетия. И все это благодаря его выгодному расположению в живописном оазисе, практически в центре сети дорог Великого шелкового пути.
\end{abstract}

Ключевые слова: Центральная Азия, исторические памятники, Ходж Ахмеда Яссави, Арыстан-Баб, Дворец Ак-Сарай

\section{INTRODUCTION}

The history of our ancient land leaves deep into the millennia. Holding an advantageous geographical position, the connecting North with the South, the East with the West, Central Asia was the important center on the road of a caravan which became history under the name of the Great Silk Way. On branches of this ancient transcontinental highway not only trade developed - there was an active process of mutual enrichment of ideas, cultures, traditions, religions, crafts and technologies.

One of the types of the works directly concerning cultural heritage, demanding greater financial influences, but which aren't receiving 
the due amount of financing is carrying out engineering-geological and geotechnological researches of historical monuments of architecture of Central Asia.

Environmental problems are connected with changes of historically developed geological and hydrogeological mode. In particular is a raising of ground waters and increase in their structure of concentration of salts, increase in moisture content and salt in the soil. These phenomena started promoting actively deformation of designs and an intensive erosion of walls and bases of monuments of architecture. Especially strongly historical buildings of the cities located in low territories of Central Asia (Bukhara, Khiva) suffer. Now the listed above negative facts negatively influence and the architecture monuments which are in rather favorable foothill territories of Central Asia: in such as Samarkand, Shakhrisabz, Shymkent, etc. however here increase in humidity in soil and raising of ground waters is generally connected with a human factor: urbanization and development of communication systems. For this reason studying of this problem needs to be conducted in two directions: in the global - change of a geoecological situation of Central Asia, in local scale - to look for evidence-based ways of decrease in level of its influence for the purpose of preservation of masterpieces of world famous monuments of architecture. We will begin with the main thing: a geoecological situation in the region. Central Asia is located between two large rivers: Amu Darya and Syr-Darya which rivers use Uzbekistan, Kazakhstan, Turkmenistan, Tajikistan and Kyrgyzstan (Figure 1).

The territory has a various and difficult relief: from the East ridges of Gissar - Scarlet and Tien Shan, from the West extensive desert plains of Kizilkum and Kara Kum. Both rivers in the northwest flow into the Aral Sea adjoining from the North and the West of a plateau Ustyurt and from Kyzylkumami's southeast. The Aral Sea on a map appears as a third largest inland reservoir of the planet and is after the North American lake Top and the Caspian Sea.

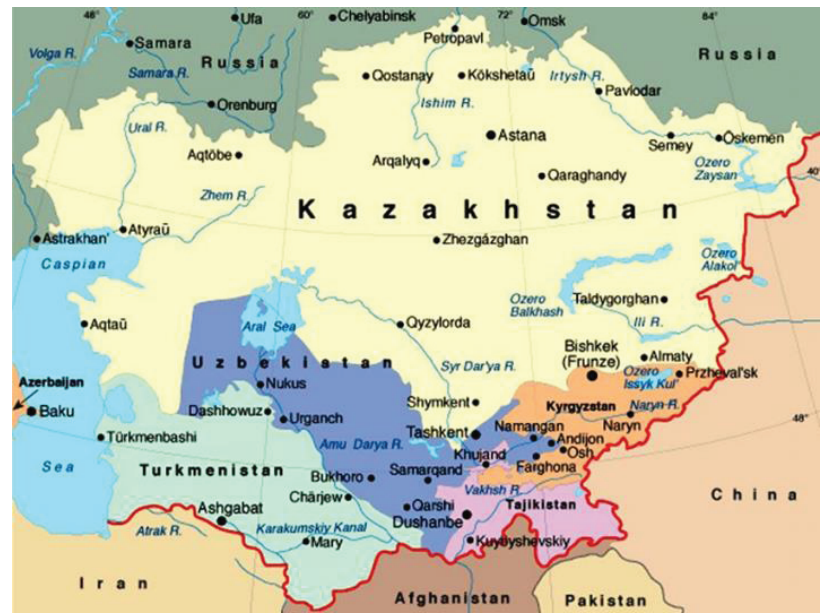

Figure 1. Map of the Central Asian Republics (Kazakhstan, Uzbekistan, Turkmenistan, Tajikistan and Kyrgyzstan).

The questions of geotechnical researches and also the reasons resulting in need of strengthening of the foundations of monuments of architecture were considered in the works by B.I. Dalmatov, R.A. Mangushev, V.M. Ulitsky, Y. Iwasaki, E.M. Pashkin, V.A. Vasenin, A.I. Polishchuk, A.Z. Khasanov, I.I. Usmankhodzhayev, C.Viggiani, C. Tsatsanifos, T.O. Zhunissov, A.G. Shashkin, M.B. Lisyuk, R.E. Dashko and other scientists. Considerable interest in questions of restoration of monuments of architecture of Central Asia was shown by K. Tuyakbayev, S. S. Agitayev, A. B. Seydaliyeva. Materials on memorial architecture of Kazakhstan and Central Asia were considered in various aspects in works of A.Kh.Margulan, K. A. Akishev, T.N. Senigova, A. G. Maximova , K. M. Baypakov , V.Olkhovskiy, V. L. Voronina, G. A. Pugachenkova, M. M. Mendikulov, E.M. Baitenov, G.G. Gerasimova, V. V. Konstantinova, T.D. Dzhanysbekov, M. B. Hodzhayev, S. S. Dzhambulatov, B. T. Tuyakbayeva, S. I. Adzhigaliyeva, B. A. Glaudinov, K. S. Abdurashidov, etc.

We will provide some statistical data. Development of droughty lands began from $30^{\text {th }}$ years of the XX century. In 10 years only in the territory of Uzbekistan, more than $250 \mathrm{~km}$ of channels with a total area of irrigation of 420 
thousand hectares were laid. Since 1960, the irrigating network increased by $874 \mathrm{~km}$, and the area - by 690 thousand hectares. Now the total length of irrigation canals makes over 160 thousand $\mathrm{km}$ only across Uzbekistan, which select from sources more than $50 \mathrm{~km}^{3}$ waters in a year, and across Central Asia in general to 100 $\mathrm{km}^{3} /$ year. For this period, the area of the irrigated lands increased by four times and made more than 3.5 million hectares. Since this period, inflow of water to the Aral Sea is reduced: 1970 - to $36 \mathrm{~km}^{3}, 1980$ - to 10 $\mathrm{km}^{3} /$ year, and in 1990 practically to zero.

As a result of it Aral's level decreased more than $15 \mathrm{~m}$, the volume of water was reduced more than $70 \%\left(600 \mathrm{~km}^{3}\right)$, and the area - more than a third. In deep Arale it was possible to catch to 1.5 million centners of fish a year. Since 1960 salinity of water reached $30 \%$ that led to death of fresh-water fishes, such as a sazan, the bream, the zherekh. From a bottom of the drained Aral annually norths rise in the atmosphere of 15-75 million $t$ of dust. In Priaralye on each hectare settles to $520 \mathrm{~kg}$ of dust, sand and salts.

In the course of accumulation of drainage and washing waters in lowlands of deserts lakes which sizes increase since 1960 were formed. For example, borders of Arnosay (Syr-Darya) reached the menacing sizes. Such new growth leads to local change of a climatic situation. In particular to flooding of natural pastures, bogging of territories and a sharp raising of the horizon of ground waters. The same situation arose in lower reaches of Amu Darya (the lake Sarikamysh).

If to consider that the average consumption of water on watering of the irrigated lands makes 9-10 thousand $\mathrm{m} 3$ on hectare (optimum 6-7 thousand $\mathrm{m} 3$ on hectare the rest on evaporation), the remained 5-6 thousand $\mathrm{m} 3 /$ hectare resupply ground waters. For this reason the level and a mineralization of ground waters in Central Asia increases practically everywhere.

It should be noted especially that the developed hydrogeological situation causes extensive damage to the geoecological environment of the historical cities of Central Asia. It is known that in the course of a raising of ground waters there is a deformation of a surface of the earth. It leads to uneven rainfall of civil and industrial buildings, constructions, and also historical monuments of architecture.

For the last decade there were serious problems connected with preservation of world famous masterpieces of architecture. In particular, the salted ground waters owing to the aggression in relation to construction materials as a result of difficult physical and chemical processes start erodirovat intensively underground and elevated designs of monuments therefore often there are deformations, and in certain cases and their final fracture. As an example, it is possible to bring catastrophic destruction of one of minarets of the Chor-Minor complex, strong deformations of a complex Tim Abdulkhana, a complex ARC and an inclination of minarets in Bukhara (Figure 2) or deformations of some monuments in Samarkand, the Ichang-Kala complex in Khiva.

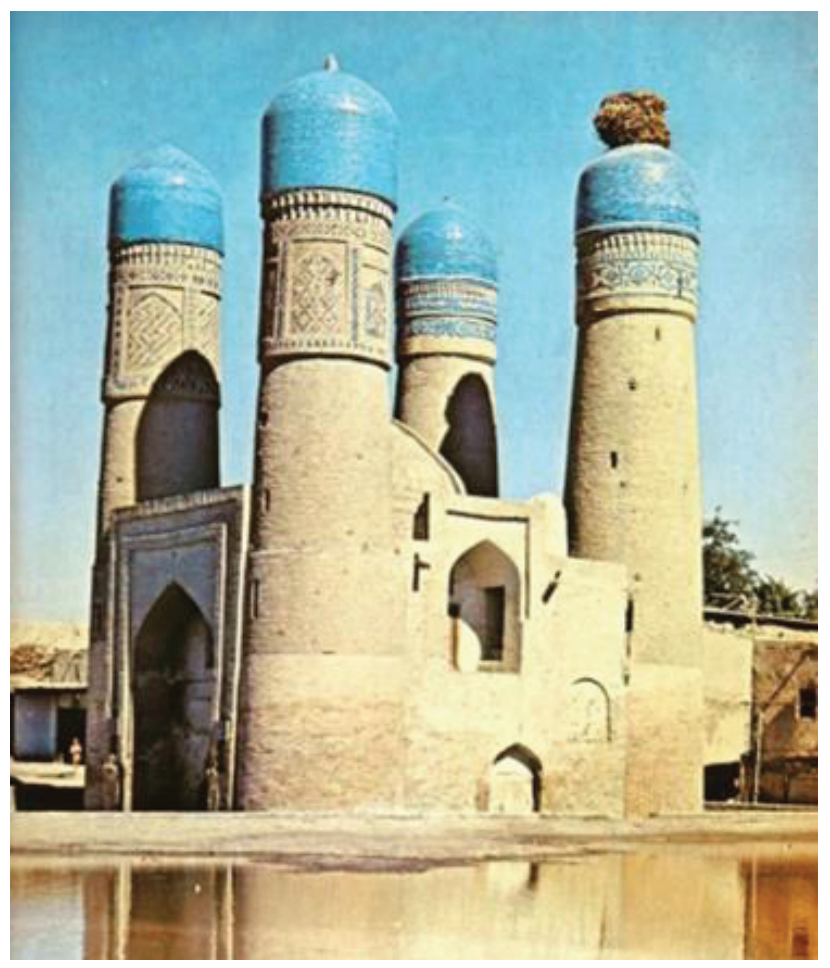

Figure 2. The Chor-Minor Complex in Bukhara.

Influence of the mineralized ground waters on 
the historic centers located in low territories of an oasis, such as Bukhara and Khiva is most notable. Both of these cities are located in the valley of Amu Darya. The large-scale irrigational works described above led to sharp increase of ground waters that respectively worsened historically developed geological situation in the region. For example, the construction of the Tashauzsky branch of the channel $180 \mathrm{~km}$ long begun 1982 with a capacity of $400 \mathrm{~m}^{3} / \mathrm{sec}$. (the channel is laid in 12 $\mathrm{km}$ from the city of Khiva) worsened a condition of 175 thousand hectares of the old irrigated arable lands of Kharezm and led to an aggravation of the hydrogeological mode of the ancient city of Khiva. Process of bogging and secondary salinization affected fauna and flora. So as a result of change of habitat aggression of termites which started destroying intensively structures and especially materials of elements of designs of historical monuments increased.

At construction of monuments of architecture in the IX-X centuries it was applied (a ceramic square brick Muslim) to construction of walls, a flooring of floors of rooms and the yards by the sizes: $23 \times 23 \times 3 \mathrm{~cm} ; 12 \times 12 \times 3 \mathrm{~cm} ; 60 \times 63 \times 6,5 \mathrm{~cm}$. In the X-XI centuries also applied a brick of $21 \times 21 \times 2,5 \mathrm{~cm} ; 24 \times 24 \times 4 \mathrm{~cm}$; in the XII-XVI centuries also applied a brick the sizes of the parties of 24-28 cm and 4,5-7 cm thick. Water absorption of wall ceramics fluctuates ranging from 18 to $30 \%$ depending on material. The compressive strength of 50-300 kg / cm (5-30 $\mathrm{MPa}$ ). Frost over 50 cycles (Voronina V.L. 1953).

\section{THE SHORT DESCRIPTION OF HISTORICAL MONUMENTS OF ARCHITECTURE OF CENTRAL ASIA}

\subsection{The mausoleum of Hodge Ahmed Yassavi (XIV-XV cen.).}

Architectural complex of Hodge Ahmed Yassavi in Turkestan - the bright example of architecture of timurids time which united different rooms, various on function, in the walls: dzhamaatkhana, gurkhana (tomb), big and small aksara, kitapkhana, askhana, kudukhana and numerous hudzhra. Because of such variety of functions of the building scientists can't come to a consensus concerning its name in any way, and therefore call it differently: mausoleum, mosque, memorial complex, hanaka. Each of names characterizes only one of functions of this grandiose complex and doesn't reflect all services and rituals provided in it. Recently in a circle of experts it most often call "hanaka" - the term which it is accepted to call hospices (monasteries) of dervishes (Akishev K.A., Ageyeva Ye.I. 1958).

The Hanaka was built according to instructions of the emir Timur in 1399 on a place of burial of Hodge Ahmed Yassavi who died in the XII century. The official history of Timur "The book of victories" ("Zafar-name") connects a narration about a laying of the building with events of the end of 1397 when Timur solemnly made ziarat (worship) on Ahmed Yasavi's grave. According to "The book of victories", during stay in the Yassy city Timur instructed in creation here, on the suburb of its possession, a grandiose construction, worthy to Hodge Ahmed Yassavi's memory. It had to glorify Islam, promote its further distribution, facilitate government of extensive edge.

Timur's instructions on construction were executed strictly. According to the legend when erected the mausoleum, from a humdan (b rick-works) which was in Sauran sity workers who handed over a brick for construction were placed. In 1405 Timur died, and works on Ahmed Yassavi's mausoleum stopped. Remained incomplete portal part (peshtak) and finishing of interiors of some rooms of the building.

As it was told earlier, Ahmed Yassavi's hanaka the multipurpose construction including a number of rooms: to a dzhamaatkhana - the hall for meetings, a tomb - a place of burial of Ahmed Yassavi, a mosque, big and small aksarai - rooms for meetings, debates; to a kitabkhana - the room for census of papers, 
storage of books and documents; to an askhana the room where ritual food prepared; to a kudukhana- the room with a well; hudzhra rooms for attendants of a hanaka and pilgrims. All rooms of a hanaka are grouped in composition in a rectangle about 50 in size $(60$ $\mathrm{m}$ and $15 \mathrm{~m}$ high. Domes and arches of a portal tower to $38 \mathrm{~m}$ (Figure 3).
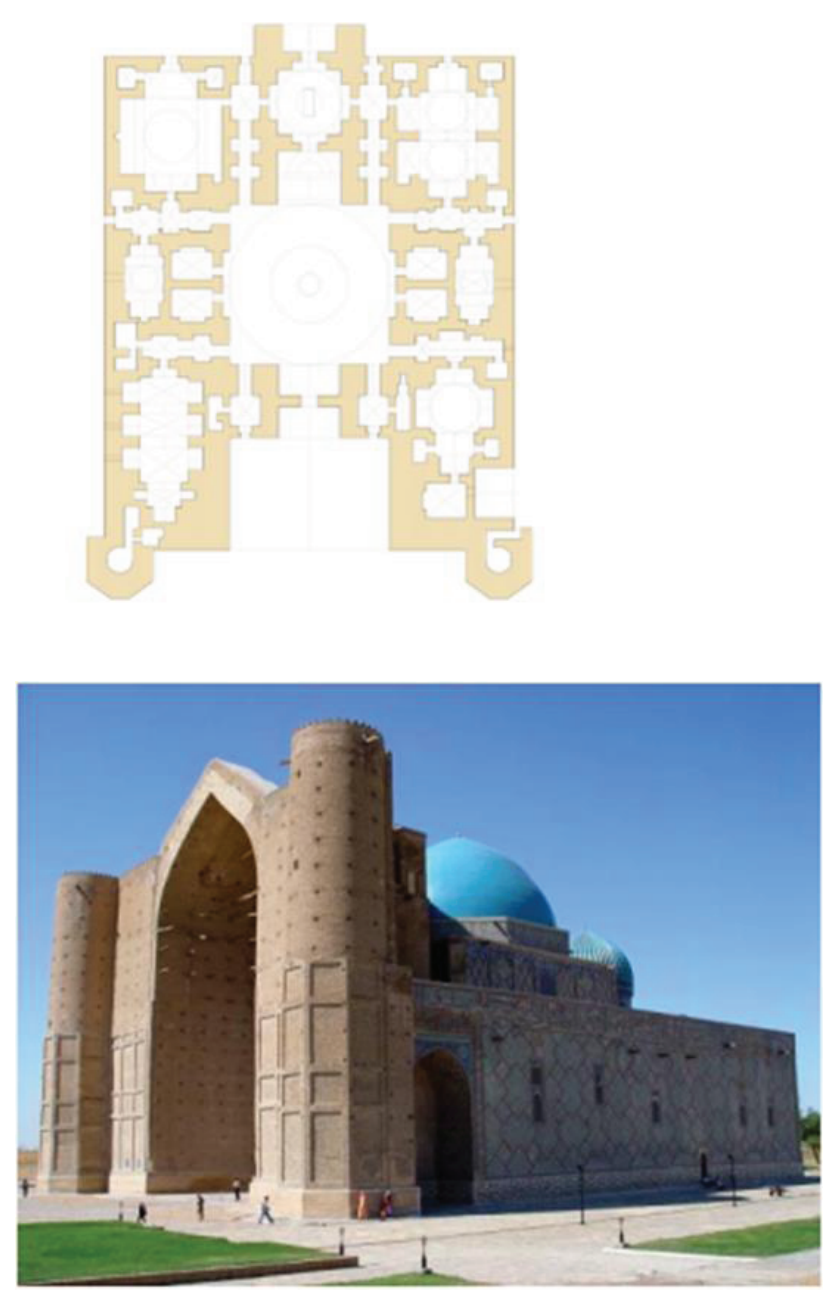

Figure 3. Schematical plan and general view of the mausoleum of Hodge Ahmed of Yassavi.

The connecting link of all rooms - a dzhamaatkhana is a smart room of a complex, square in the plan with the parties, equal 18,2 meters, is covered by the largest of remained in Central Asia a sphere and conic dome with an unary cover. Here passed meetings and group meeting (zikra) of dervishes. In the center of the hall there is a ritual cauldron (from here another, more used name of the hall - Kazanlyk) cast according to the legend, from an alloy of seven metals. A cauldron is a symbol of a unification and hospitality. Diameter its 2.2 meters, weight is two tons. The exaggerated sizes of a cauldron are dictated by ancient beliefs of Turkic tribes: the edge of a cauldron has to be at height of a mouth of the person which to it goes. The surface of a cauldron is decorated with three belts of relief inscriptions against a vegetable ornament.

Top says that this cauldron for water - Timur's gift to the construction erected in memory of Hodge Ahmed Yassavi. In average of the word:"Be blessed", year of production of a cauldron - 1399 and a name of the master Abdulgazizibn Sharafutdin from Tabriz. In the lower it is told: "Kingdom to Allah". Handles of a copper have an appearance of flowers of a lotus and alternate with round ledges (Tuyakbayeva B., Proskurin A. 1989).

The Hanaka of Ahmed Yassavi played a significant role in formation of the Turkestan necropolis, which developed on a place of the early medieval cemetery presented by several over sepulchral constructions and mausoleums with traditional orientation of their entrances to the southwest - in the direction to Mecca (Figure 4).

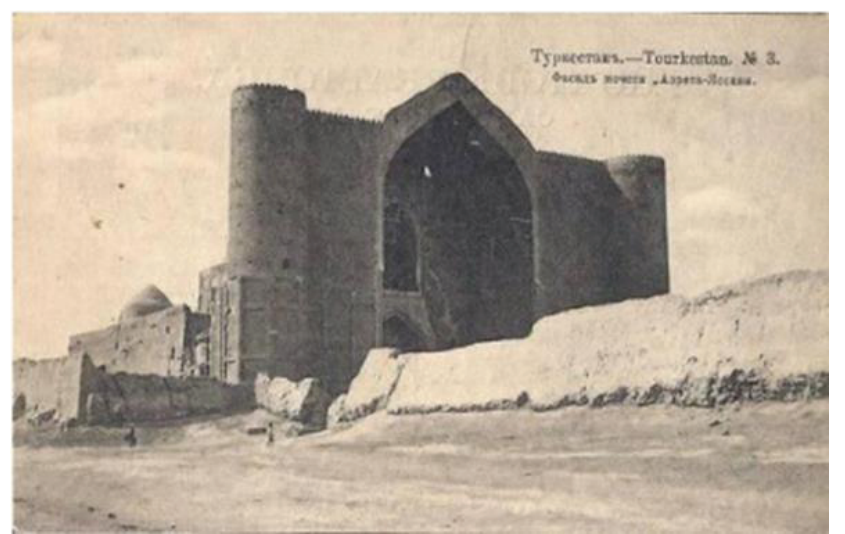

Figure 4. .Old photos of the mausoleum of Hodge Ahmed Yassav.

\subsection{The mausoleum of Arystan-Bab (XIV-XV cen.).}

The mausoleum was built over a grave of the famous religious mystic ArystanBab, living in 
the XII century in the Southern Kazakhstan region. The first construction of the mausoleum belongs to the XIV-XV centuries. From it carved wooden columns of an ayvan remained. In the XVIII century on a place of the ancient mazar destroyed by an earthquake two dome construction with ayvan, leaning on two carved wooden columns was constructed. The building of the XVIII century collapsed and in 1909 was built up a new about what the inscription on one of frieze cartouches says. Now above Arystan-Bab's grave there is a mausoleum of 3 0x13 m (Figure 5).

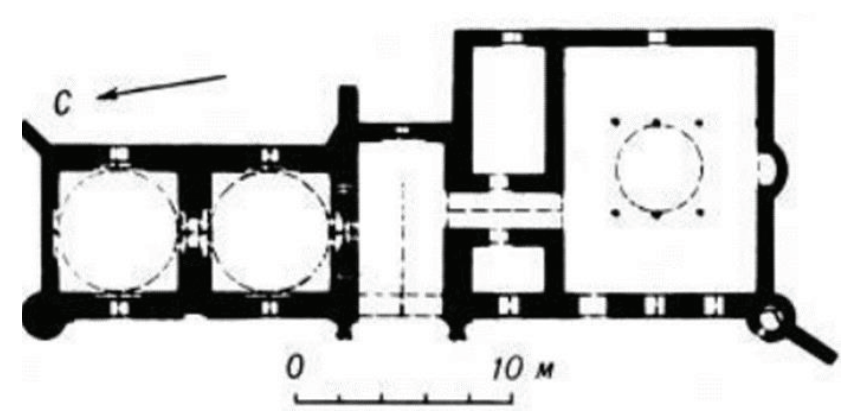

Figure 5. .Schematic plan of the mausoleum Arystan-Bab.

In 1971 because of the high level of the ground waters which led it to a critical condition, the mosque was taken down and built up anew. The building i s built of a zhzheny brick on alabaster solution, in a front laying of walls (Figure 6).

The building behind little change in an azimuth is focused from the East to the west. Two square rooms of tombs adjoin to each other and form the extended rectangle. From the West the square of the room of a mosque with hotel and taratkhany for ablution adjoins. Tombs and a mosque connect the ayvan.

The main facade is solved simply and at the same time impressively. It consists of a portal, two walls and angular towers. Instead of massive medieval portals, here the easy portal which is decoratively processed with a lancet arch, leaning on walls of an ayvan. The arch has from two parties of a frame in the form of columns buttresses with sockets on the center of the planes of buttresses.
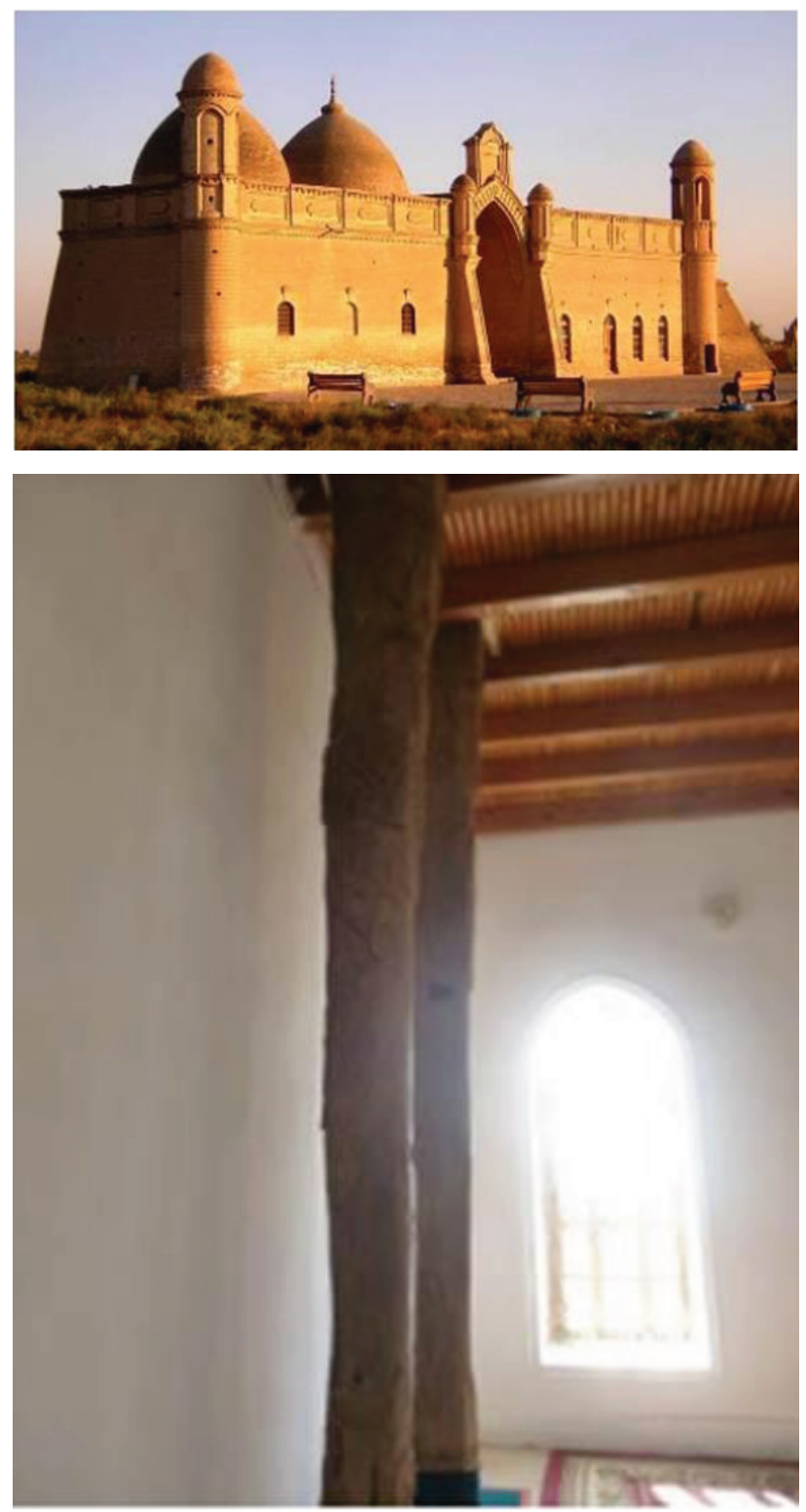

Figure 6. The modern view of the mausoleum Arystan-Bab and two remained columns of the XIV-XV century.

The lancet arch is executed by a wedge-shaped laying where the strelchatost is reached by wedge-shaped wedgeshaped bricks (Margulan A.KH., Basenov T.K., Mendikulov M.M. 1959). Tombs have dome overlapping. Domes are based upon low deaf drums. Transition from a plan square to domes is carried out by means of angular tromp without stalactite decorative fillings. 


\subsection{The Palace Ak-Sarai (XV cen.).}

At Amir Timur time in northwest part of Shakhrisabz the huge palace Ak-Sarai surpassing in scale even the government residence Kuk-Sarai in Samarkand ("Ak" in translation - white, majestic, noble was built; "sarai" - the palace). The main construction works were carried out in 1380-1396. Along with local masters, masters were involved in construction and finishing of the palace from Khwarezm and other subdued countries. The building of the palace was destro yed already in the second half of the XVI century. At Sheybanids, seeking to rub memory of greatness Timurids.

On a legend a cause of destruction was rage Abdullah khan II who, come nearer to the city, saw in the distance high structures of Ak-Sarai. Having considered that it it is already close to the city, the khan rushed off at a gallop, but, having tired out a horse to death, didn't reach to Shakhrisabz. Up to now only ruins of a grandiose portal remained (Figure 7).

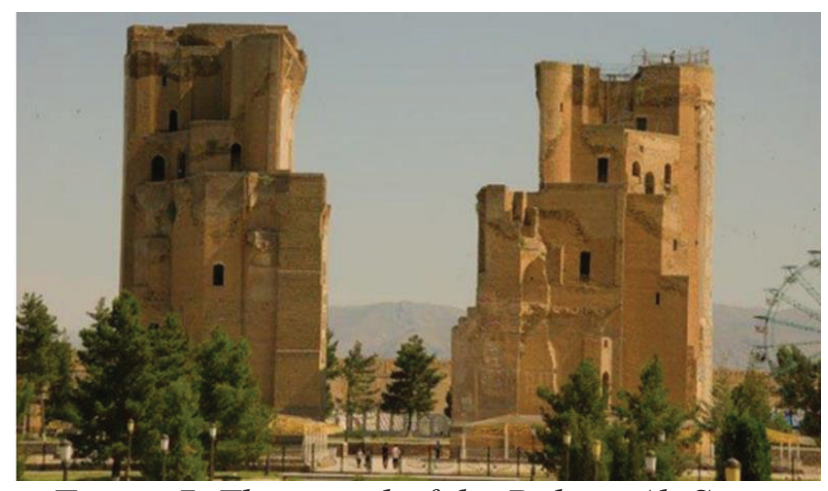

Figure 7. The portal of the Palace Ak-Sarai.

Test time was passed by its lateral tower foundations. Long ago the arch between lateral towers which had flight in $22 \mathrm{~m}$ collapsed. Modern height of towers about $38 \mathrm{~m}$, and in the past it reached $50 \mathrm{~m}$. In them there were spiral staircases conducting on the top part of a portal which according to messages of contemporaries was trimmed by a gear parapet. Descriptions of Palace Ak-Sarai are available in the diary of the Spanish ambassador Klavikho who visited here in 1404 and also in work "Baburnam" of the beginning of the XVI century. All grandiose construction of the Palace Ak-Sarai differed in skillful decorative finishing. On a portal of the Palace Ak-Sarai heraldic images of a lion and the sun, and also Amir Temur's sign in the form of three rings were laid out by a mosaic. One of texts of palace inscriptions says: "If you doubt our greatness - look at our constructions". On a mosaic plait of a portal the name of the Iranian master of facing Mahomed Yusuf Tebrizi remained.

In the past behind a huge portal of the palace there was an extensive yard with the pool from which the set of mosaic tiles remained. From the South the palace was adjoined by a garden in which the pavilion for receptions and feasts which vaulted portal was on the main axis opposite to an entrance was built. As Klavikho reports, the reception halls "were painted with gold and an azure, and are revetted with tiles, and the ceiling all is gilded". On a cross axis from two parties also there were small portals rooms for which served for work of "divan" the State Council. The yard was covered by two-storeyed building (Zasypkin B.N. 1931).

\subsection{The complex Poi-Kalyan (XII-XVI cen.).}

Minaret Kalyan (Great) is the main symbol of sacred Bukhara. The minaret served not only to convoke Muslims to a prayer, but was a symbol of the power and power of spiritual governors. The bottom of a minaret had the central ensemble of Bukhara - Poi-Kalyan - literally "The bottom great". A minaret - one of the highest buildings of Bukhara, its height of 46,5 meters with the lower diameter of 9 meters, a construction of a conic form with a lamp above (Figure 8). The minaret is ornated - the cylindrical body is laid out by strips of a $f$ lat and relief laying, revealing rotundity of a construction at any lighting. The lamp dome, unfortunately, didn't remain. It is possible to get to a minaret from a roof of a cathedral mosque to which it is connected by transition. In a tower there is a helicoid ladder with 140 steps. On eaves there is an inscription about its construction in 1127. Also the name of the architect - Bako is mentioned. 


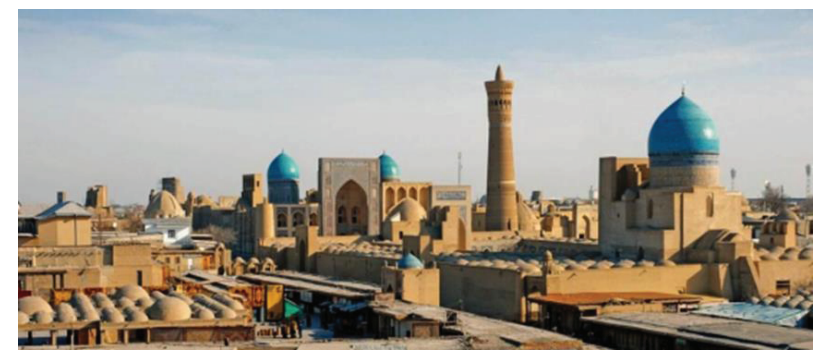

Figure 8. View of a minaret and a mosque Kalyan in Bukhara.

The mosque Kalyan in a modern look was constructed at the beginning of the XVI century. At the first Sheybanids time. Since then five centuries, excepting decades of Soviet period, it acts as the main cathedral mosque of Bukhara. The mosque replaced with itself the old karakhanids mosque of the XII century built along with a minaret Kalyan. The scale of this sheybanids mosque is comparable to temurids cathedral mosques in Samarkand and Herat. It concedes to Bibi-Hanym mosque in Smarkanda on the volume of structures, but, having dimensions of $130 \times 80 \mathrm{~m}$, surpasses it in the area.

\section{CONCLUSION}

For the last decade there were serious problems connected with preservation of world famous masterpieces of architecture. In particular, the salted ground waters owing to the aggression in relation to construction materials as a result of difficult physical and chemical processes start erodirovat intensively underground and elevated designs of monuments therefore often there are deformations, and in certain cases and their final fracture.

Ancient technologies of construction of the bases are studied. According to tests follows that during the summer period of time process of natural drying of clay takes place rather intensively and makes about $10 \%$ in days. During $t$ his period the average size of density of soil reached $\rho d=16,5 \mathrm{~g} / \mathrm{cm} 3$ that is rather high. As showed laboratory researches, at such density soil becomes almost not collapsible.
Thus, ancient masters easily reached the high density of soil which in modern conditions is reached thanks to use of heavy machinery.

At the construction time of monuments of architecture in the IX-X centuries the ceramic square brick (Muslim) was applied to construction of walls, a flooring of floors of rooms and the yards by the sizes: $23 \times 23 \times 3 \mathrm{~cm}$; $12 \times 12 \times 3 \mathrm{~cm} ; 60 \times 63 \times 6,5 \mathrm{~cm}$.

In the X-XI centuries also applied a brick of $21 \times 21 \times 2,5 \mathrm{~cm} ; 24 \times 24 \times 4 \mathrm{~cm}$; in the XIIXVI centuries also applied a brick the sizes of the parties of 24-28 cm and 4,5-7 cm thick. Water absorption of wall ceramics fluctuates ranging from 18 to $30 \%$ depending on material. Strength at compression is $50-300 \mathrm{~kg} / \mathrm{cm} 2(5-30 \mathrm{MPa})$. Frost resistance is over 50 cycles.

The mosques, the madrasah, mausoleums and other monumental buildings which remained up to now give a complete idea of engineering, constructive and planning and decorative features of construction and architecture of an era of Amir Timur and Timuridov. Century achievements of the past were enriched with new receptions and perfect system.

\section{REFERENCES}

1. Voronina V.L. Drevnjaja stroitel'naja tehnika Srednej Azii [Ancient construction equipment of Central Asia]. // Arhitekturnoe nasledstvo, 1953, Vol. 4, pp. 3-35 (in Russian).

2. Akishev K.A., Ageyeva Ye.I. Drevniye pamyatniki Kazakhstana [Ancient monuments of Kazakhstan]. Alma-Ata, "Kazgosizdat", 1958, 60 pages (in Russian).

3. Tuyakbayeva B., Proskurin A. (1989). Mirovozzrencheskiye osnovy funktsional'no-planirovochnoy struktury khanaki Akhmeda Yasavi [Worldviews of the functional planning structure of Hanaki Ahmed Yawashi]. // Pamyatniki istorii $i$ kul'tury Kazakhstana, 1989, Vol. 4, pp. 106-116 (in Russian). 
4. Margulan A.Kh., Basenov T.K., Mendikulov M.M. (1959). Arkhitektura Kazakhstana [Architecture of Kazakhstan]. Alma-Ata, "Kazgosizdat", 1959, 173 pages (in Russian).

\section{Zasypkin B.N. Pamyatniki} monumental'nogo iskusstva Vostoka [Monuments of monumental art of the East]. // Khudozhestvennaya kul'tura Sovetskogo Vostoka. Moscow, Leningrad, 1931, pp. 2149 (in Russian).

\section{REFERENCES}

1. Воронина В.Л. Древняя строительная техника Средней Азии. // Архитектурное наследство, Выпуск 4. - М.: Госиздат лит. по строительству и архитектуре, 1953 , с. 3-35.

2. Акишев К.А., Агеева Е.И. Дервние памятники Казахстана. - Алма-Ата: Казгосиздат, 1958. - 60 с.

3. Туякбаева В., Проскурин А. Мировоззренческие основы функционально-планировочной структуры ханаки Ахмеда Йаваси. // Памятники истории и культурь Казахстана, 1989, Выпуск 4, с. 106-116.

4. Маргулан А.Х., Басенов Т.К., Мендикулов М.М. Архитектура Казахстана. - Алма-Ата: Казгоиздат, 1959. $170 \mathrm{c}$.

\section{5. Засупкин Б.Н. Памятники} монументального искусства Востока. // Художественная культура Советского Востока. - М.: - Л., 1931, с. 21-49.

A.Zh. Zhussupbekov, Professor, Dr.Sc.; Department of Civil Engineering, L.N. Gumilyov Eurasian National University, Kazhimukan street, 13a, NurSultan city, 010000, Kazakhstan; phone: +7 (7172) 709500;

E-mail: enu@enu.kz.

F.S. Temirova; Department of Economics, Karshi Engeneering-Economics Institute / Mustaqillikstreet, 225 (office), Karshi city, 180100, Uzbekistan; phone: 0(375) 221-09-23; e-mail: atm@qmii.uz.

A.A. Riskulov; Tashkent Institute of Design, Construction and of Automobile Roads; 20, Prospekt A. Timura, Tashkent, 100600, Uzbekistan; phone (fax): +998712321439;

E-mail: devonxona@tayi.uz

A.R. Omarov; Department of Civil Engineering, L.N.Gumilyov Eurasian National University, Kazhimukan street, 13a, NurSultan city, 010000, Kazakhstan; phone: +7 (7172) 709500; e-mail: enu@enu.kz.

Жусупбеков А.Ж., профессор, доктор технических наук; Евразийский национальный университет им. Л.Н. Гумилева; 010008, Республика Казахстан, г. Астана, ул. Сатпаева, д. 2, Тел: +7 (7172) 709500; E-mail: enu@enu.kz.

Темирова Ф.С.; Каршинский инженерноэкономический институт; 180100, Узбекистан, г. Карши Кашкадарьинской области, ул. Мустакиллик, д. д. 225; тел. 0(375) 221-09-23; e-mail: atm@qmii.uz.

Рискулов А.А., Ташкентский институт по проектированию, строительству и эксплуатации автомобильных дорог; Республика Узбекистан, город 100060, Ташкент, проспект А. Тимура, дом 20;

тел. (факс): +998712321439;

E-mail: devonxona@tayi.uz

Омарова А.P.; Евразийский национальный университет им. Л.Н. Гумилева; 010008, Республика Казахстан, г. Астана, ул. Сатпаева, д. 2, тел: 7 (7172) 709500; e-mail: enu@enu.kz. 